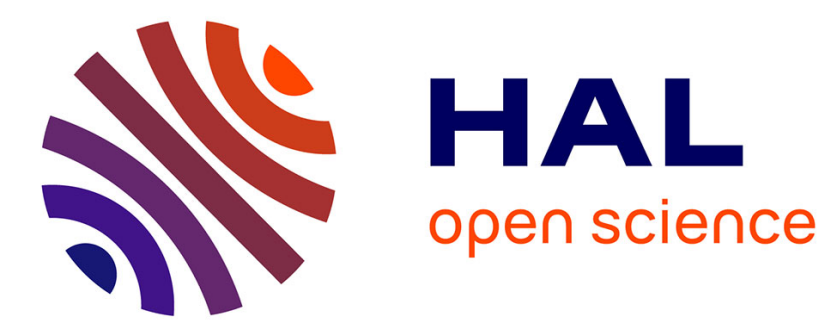

\title{
Dynamics of $\mathrm{Cl}+$ Propane, Butanes Revisited: A Crossed-Beam Slice Imaging Study
}

Baptiste Joalland, Yuanyuan Shi, Nitin Patel, Richard van Camp, Arthur G. Suits

\section{- To cite this version:}

Baptiste Joalland, Yuanyuan Shi, Nitin Patel, Richard van Camp, Arthur G. Suits. Dynamics of Cl + Propane, Butanes Revisited: A Crossed-Beam Slice Imaging Study. Dynamics of Molecular Collisions, Jul 2013, Granlibakken, CA, United States. hal-01246965

\section{HAL Id: hal-01246965 https://hal.science/hal-01246965}

Submitted on 21 Dec 2015

HAL is a multi-disciplinary open access archive for the deposit and dissemination of scientific research documents, whether they are published or not. The documents may come from teaching and research institutions in France or abroad, or from public or private research centers.
L'archive ouverte pluridisciplinaire HAL, est destinée au dépôt et à la diffusion de documents scientifiques de niveau recherche, publiés ou non, émanant des établissements d'enseignement et de recherche français ou étrangers, des laboratoires publics ou privés. 


\section{Dynamics of $\mathrm{Cl}+$ propane, butanes revisited: a crossed-beam slice imaging study}

Baptiste Joalland, Yuanyuan Shi, Nitin Patel, Richard Van Camp and Arthur G. Suits

Department of Chemistry, Wayne State University, Detroit, MI USA

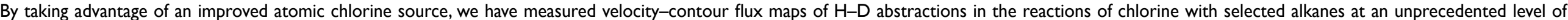

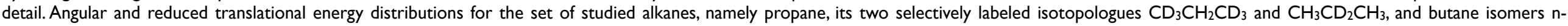

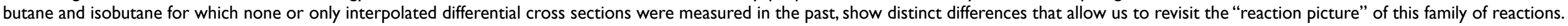

\section{Experimental}

Crossed-beam DC slice imaging set-up

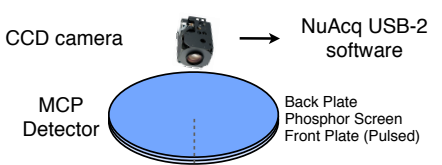

TOF axis

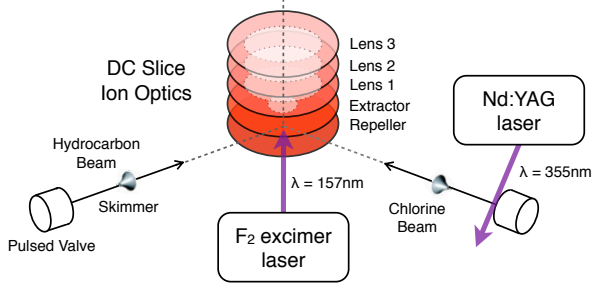

- Radical hydrocarbon products are ionized with a vUB beam at $157 \mathrm{~nm}$.
- The ionized cloud is accelerated and stretched by a set of four ion optics

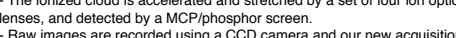
- Raw images are reya
program NuAca-2.

A high-density $\mathrm{Cl}$ source: photolysis/ablation
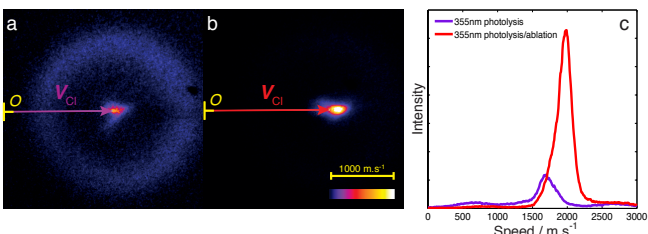

Raw images at $\mathrm{m} / \mathrm{z}=35$ without $(\mathrm{a})$ and with (b) ablation

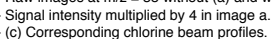

Advantages:

ratio $=>$ Unfocused probe

- Probe/interaction region overlap

No mentiple photilux correction

$\Rightarrow$ Product selection with ionization energies

\section{Thermochemical data}

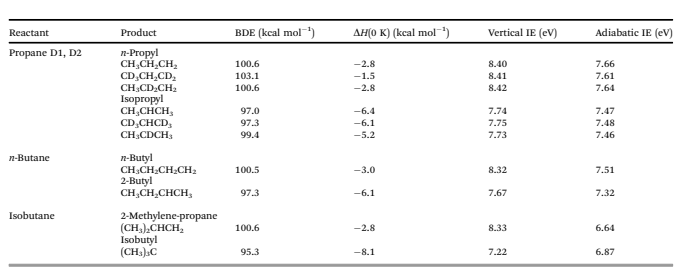

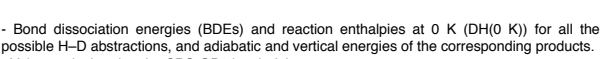
possible $H$-D abstractions, and adiabatic and vertic
- Values calculated at the CBS- $0 B 3$ level of theory.

$\Rightarrow>$ Velocity-flux maps measured for secondary $H(D)$ abstraction in isobutane.

\section{Imaging}

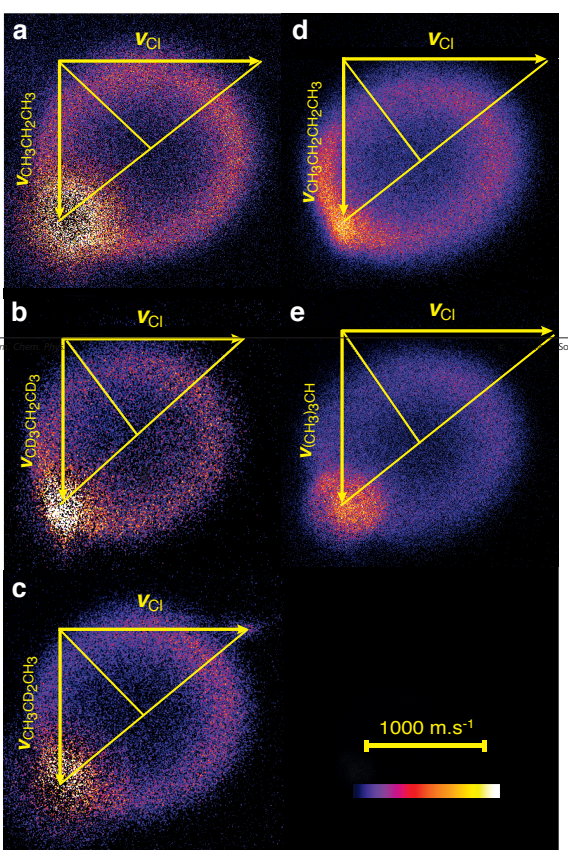

DC sliced raw images of reactive scattering and nominal Newton diagrams for the

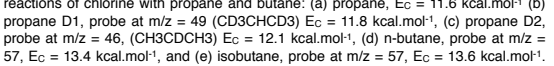

\section{Differential Cross Sections}
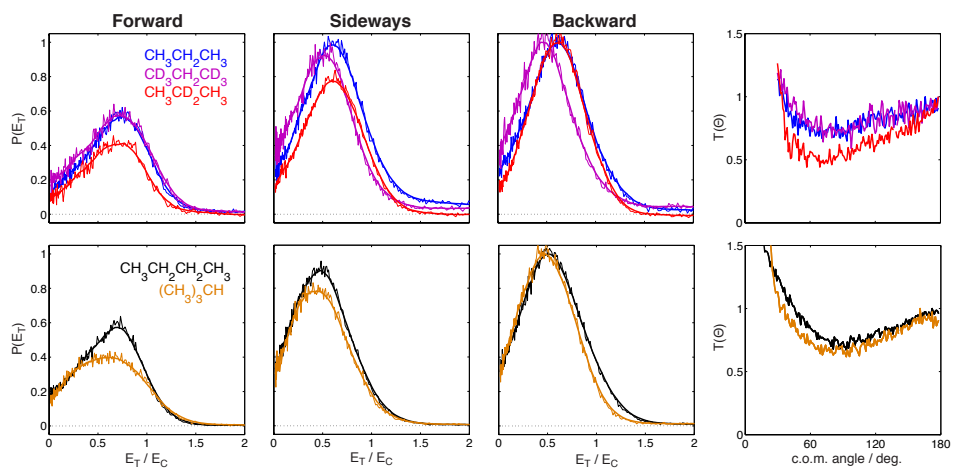

- Reduced translational energy distributions for forvard $130-60$
scattered products and the center-or-mass angular distributions.

deg.), sideways (60-120

c.o.m. angle/ / deg. - Top panel corresponds to propan
- Each distribution is normalized to
in this range of integrated angles.
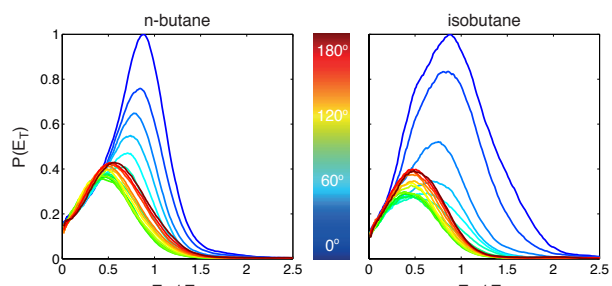

$\mathrm{E}_{\mathrm{T}} / \mathrm{E}_{\mathrm{C}}$

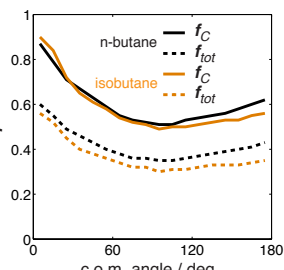

:Reduced ranslational energy distributions tor 10 deg. steps of the angular distributions of reactions of chlorine with

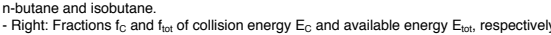

\section{Conclusions}

Propane and isotopologues:

- Concerning translational energy recoil, $\mathrm{FW}$ and $\mathrm{SW} \mathrm{CD}_{3} \mathrm{CH}_{2} \mathrm{CD}_{3}$ distributions peak at lower $\mathrm{ET}^{*}$ than regure

- The angular distribution of $\mathrm{D} 2$ is affected by the deuteration.

=> a kinematic effect

Butane isomers:

Compared to n-butane distributions, isobutane distributions exhibit a more sharply peaked angular distribution with a broader translational energ/ $\Rightarrow>$ vibrationally excited $\mathrm{HCl}$ or steric hindrance effect?

$\Rightarrow$ Need for state-resolved experiments
This work is funded by

(0) ENERGY 